TABLE I.-Micrococcus Melitensis.

\begin{tabular}{|c|c|c|}
\hline $\begin{array}{l}\text { No. } \\
\text { of } \\
\text { Tube. }\end{array}$ & Contents of Capillary Sedimentation Tube. & $\begin{array}{l}\text { Sedimentation } \\
\text { Effect after } \\
24 \text { Hours. }\end{array}$ \\
\hline I & Unmixed dead bacterial culture & Practically nil. \\
\hline $\begin{array}{l}2 \\
3\end{array}$ & $\begin{array}{l}\text { Dead bacterial" culture mixed with än equal quan- } \\
\text { tity of a ro-fold diluted non-specific serum }\end{array}$ & $\ddot{\prime \prime}$ \\
\hline 4 & $\begin{array}{l}\text { Living bacterial culture treated in exactly the } \\
\text { same manner }\end{array}$ & " \\
\hline $5 a$ & $\begin{array}{l}\text { Dead bacterial culture mixed with an equal quan- } \\
\text { tity of a ro-fold diluted specific serum }\end{array}$ & Complete \\
\hline $5 b$ & $\begin{array}{l}\text { Living bacterial culture treated in exactly the same } \\
\text { manner }\end{array}$ & " \\
\hline $6 a$ & $\begin{array}{l}\text { Dead bacterial culture mixed with an equal quan- } \\
\text { tity of a } 50-\text { fold diluted specific serum }\end{array}$ & $"$ \\
\hline $6 b$ & $\begin{array}{l}\text { Living bacterial culture treated in exactly the same } \\
\text { manner }\end{array}$ & $"$ \\
\hline $7 a$ & $\begin{array}{l}\text { Dead bacterial culture mixed with an equal quan- } \\
\text { tity of a roo-fold diluted specific serum }\end{array}$ & " \\
\hline $7 b$ & $\begin{array}{l}\text { Living bacterial culture treated in exactly the same } \\
\text { manner }\end{array}$ & " \\
\hline $\begin{array}{l}8 a \\
8 b\end{array}$ & $\begin{array}{l}\text { Dead bacterial culture mixed with an equal quan- } \\
\text { tity of a } 500 \text {-fold diluted specific serum } \\
\text { Living bacterial culture treated in exactly the }\end{array}$ & 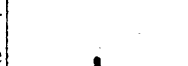 \\
\hline $\begin{array}{l}9 a \\
Q b\end{array}$ & $\begin{array}{l}\text { manner } \\
\text { Dead bacterial culture mixed with an equal quan- } \\
\text { tity of a r,ooo-fold diluted specific serum } \\
\text { Living bacterial culture treated in exactly the same }\end{array}$ & \\
\hline $\begin{array}{l}\text { roa } \\
\text { sob }\end{array}$ & $\begin{array}{l}\text { manner } \\
\text { Dead bacterial culture mixed with an equal quan } \\
\text { tity of a 2.00o-fold diluted specific serum } \\
\text { Living bacterial culture treated in exactly the same }\end{array}$ & r \\
\hline II $a$ & $\begin{array}{l}\text { manner } \\
\text { Dead bacterial culture mixed with an equal quan- }\end{array}$ & \\
\hline$I I b$ & $\begin{array}{l}\text { Living bacterial culture treated in exactly the same } \\
\text { manner }\end{array}$ & $"$ \\
\hline $\begin{array}{l}12 a \\
12 b\end{array}$ & $\begin{array}{l}\text { Dead bacterial culture mixed with an equal quan- } \\
\text { tity of a 5,000-fold diluted specific serum } \\
\text { Living bacterial culture treated in exactly the sare } \\
\text { manner }\end{array}$ & $\begin{array}{c}\text { Marked but not } \\
\text { complete. } \\
\text { " }\end{array}$ \\
\hline
\end{tabular}

Table II.-Bacillus Typhosus.

\begin{tabular}{|c|c|c|}
\hline $\begin{array}{c}\text { No. } \\
\text { of } \\
\text { Tube. }\end{array}$ & Contents of Capillary Sedimentation Tube. & $\begin{array}{l}\text { Sedimentation } \\
\text { Effect after } \\
24 \text { Hours. }\end{array}$ \\
\hline I & Unmixed dead bacterial culture & Practically nil. \\
\hline $\begin{array}{l}2 \\
3\end{array}$ & $\begin{array}{l}\text { Dead bacterial culture mixed" with än equal quan- } \\
\text { tity of a ro-fold diluted non-specific serum }\end{array}$ & ", \\
\hline 4 & $\begin{array}{c}\text { Living bacterial culture treated in exactly the same } \\
\text { manner }\end{array}$ & ", \\
\hline $5 a$ & $\begin{array}{l}\text { Dead bacterial culture mixed with an equal quan- } \\
\text { tity of a ro-fold diluted specific serun. }\end{array}$ & Complete. \\
\hline $5 b$ & $\begin{array}{l}\text { Living bacterial culture treated in exactly the same } \\
\text { manner }\end{array}$ & " \\
\hline $6 a$ & $\begin{array}{c}\text { Dead bacterial culture mixed with an equal quan- } \\
\text { tity of a } 2 \text {-fold diluted specific serum }\end{array}$ & \\
\hline $6 b$ & $\begin{array}{l}\text { Living bacterial culture treated in exactly the same } \\
\text { manner }\end{array}$ & \\
\hline${ }_{7} a$ & $\begin{array}{l}\text { Dead bacterial culture mixed with an equal quan- } \\
\text { tity of a } 40 \text {-fold diluted specific serum }\end{array}$ & , \\
\hline $7 b$ & $\begin{array}{l}\text { Living bacterial culture treated in exactly the same } \\
\text { manner }\end{array}$ & " \\
\hline $8 a$ & $\begin{array}{l}\text { Dead bacterial culture mixed with an equal quan- } \\
\text { tity of a 5o-fold diluted speciflc serum }\end{array}$ & \\
\hline $8 b$ & $\begin{array}{c}\text { Living bacterial culture treated in exactly the same } \\
\text { manner }\end{array}$ & , \\
\hline $9 a$ & $\begin{array}{l}\text { Dead bacterial culture mixed with an equal quan- } \\
\text { tity of a roo-fold diluted specific serum }\end{array}$ & $\begin{array}{l}\text { Marked but } \\
\text { incomplete. }\end{array}$ \\
\hline $9 b$ & $\begin{array}{c}\text { Living bacterial culture treated in exactly the same } \\
\text { manner }\end{array}$ & , \\
\hline
\end{tabular}

bacterial cultures to the ordinary practitioner, and espe. cially to the practitioner abroad and to the medical officer who is at sea or on military service. It will obviously be possible for every medical man to obtain a supply of capsules of dead typhoid and Malta fever bacteria for serum diagnosis from a central bacteriological laboratory. He will be able to carry about these cultures without risk, and he will not need to take precautions against infection when he is employing them in the serum diagnosis of doubtful cases of fever. His whole equipment in connection with serum diagnosis may, in fact, be narrowed down to a supply of these sapsuies of dead bacteria, a small supply of glass tubing of say $1^{3} 6$ to $\frac{1}{4}$-inch diameter, and the blowpipe apparatus which is described below. Any man who is provided with these requisites can easily teach himself to make such blood capsules and sero-sedimentation tubes as are figured in the British Medical Journal of January $16 \mathrm{th}$, 1897 , in connection with the paper which has already been referred to. He has only to keep in view that a capillary tube is made by heating a piece of glass tubing and then drawing it out after it has been removed from the flame.

Method of Extemporising a Blowpipe Flame for making Serosedimentation Tubes. - After casting about in various directions for a simple method of producing a blowpipe flame which sinould be practicable at a distance from a laboratory, we have found a method which we believe satisfies all requirements. This method consists in the employment of an ordinary spray producer, such, for instance, as an ether-freezing apparatus. The reservoir of the apparatus is filled with methylated spirit, and a steady current of air is driven through it by means of the hand bellows which is supplied with the apparatus. The alcohol spray is then simply ignited. We find that the flame which is produced in this manner is quite hot enough for all ordinary glass-working operations. It is, for instance, quite hot enough to enable us to draw out glass tubing into capillary sero-sedimentation tubes. The following appear $\cdot$ to bc the only points that have to be attended to in connection with the working of the flame: first, the alcohol must be tolerably finely divided (if a very coarse spray is employed the flame will not be sufficiently hot); secondly, the alcohol must be fed into the spray tube in sufficient quantity and in a regular manner (if this last 'point is not attended to the flame will be very unsteady, or it will go out and will require to be relit).

In conclusion, we desire to revert to the question of serum diagnosis by means of dead bacteria, and to draw attention to the relation between this method of serum testing and the method of typhoid vaccination which was recently proposed by us in this JourNaL. ${ }^{5}$ It will be obvious that inasmuch as the vaccine material which is employed in the vaccinations in question consists of cultures of typhoid bacteria which have been killed by exposure to a temperature of $60^{\circ} \mathrm{C}$., we have in the contents of the vaccine capsule not only a material with which we can vaccinate against typhoid, but also a material by the help of which we can determine whether a necessity for vaccination exists, and a material by the help of which we can measure the effect which is produced upon the patient by the vaccination process.

\section{NOTES AND REFERENCES.}

1 For a description of these see a paper by one of us in the BRITISR MEDICAL JOURNAL of January 16 th. 1897. '2 The death of the bacteria was in all cases verified by the inoculation of the contents of the capsules upon agar tubes. 3 This lends support to Surgeon-Major Bruce's view Brownian in character. 4 This can very easily be provided for by depressing the nozzle of the spray producer below the level of the fluid in the reservoir. 5 BRITISII MEDICAL JOURNAL, January 3oth, 1897.

\section{REMARKS ON THE OCCURRENCE OF PLAGUE PNEUMONIA.}

By Surgeon-Caprain L. F. CHILdE, I.M.S.

As plague developed in Bombay, I began to examine the bodies of all hospital patients dead after acute disease, such as fever, pneumonia, etc., to see if any of them had really died of plague without buboes; and at the end of December I met with a case which had been diagnosed as bronchopneumonia, but which turned out to be one of plague affecting the lungs, without causing any marked enlargement of the lymphatic glands - a case, in fact, of plague pneumonia ; and as this post-mortem is exactly like many others that I have since made, and is typical of the disease, a bricf account of it is subjoined.

B. L., Hindu, male, aged 25, was admitted on December $26 \mathrm{th}, 1896$, for fever and cough, said to be of seven days' duration. He was very ill; no broncho-pneumonia.

He died on December 28 th, and the necropsy was made seven hours aftcr death. The lungs showed much general engorgement and gedema, with sero-sanguineous frothy fluid in the bronchi, but no pus; the usual appearances of acute bronchitis were absent. There was one small pneumonic patch. the size of a walnut, in the early second stage. situated below the apex on the front $\mathrm{c} f$ the right lung, and two similar but smaller patches at 
the same part of the left lung; these patches stood out a little from the surface, and were airless, friable, and sank in water, each was surrounded by a dark ring of engorgement, which merged into the healthy lung, and there was recent pleurisy over the pneumonic areas. All the other organs were examined, and showed considerable engorgement, but no special lesion was observed. The cervical, the axillary, and the lumbar lymphatic glands were slightly enlarged ; the left iliac slightly enlarged, red, and soft all the other glands, including the bronchial, looked absolutely normal. Bacteriological Examination. - Cultures on agar-agar were made from the pneumonic lung and spleen, and ultimately a pure growth of the plague bacillus was obtained from each. Under the microscope the pneumonic patches in both stages showed an immense number of plague bacilli, and the rest of the lung showed a large number; the fluid in the trachea also showed very many: the spleen and blood showed a few; the left supra-trochlea and the left inguinal glands showed a fair number, and all the other glands extremely few.

This, then, was a case of plague, in which during life the symptoms pointed to disease of the lungs, and in which there were no evidences of glandular enlargement, whilst after death there was clear proof of enormous growth of plague bacilli in the lungs and of only very slight growth in the lymphatic glands. Up to the present I have made twelve post-mortem examinations on such cases, all presenting appearances similar to the above, and it is noteworthy that all the patients were brought to hospital supposed to be suffering from cough and fever, and their friends were quite unaware of the nature of the disease.

With regard to the clinical symptoms of these cases, the late Dr. M. died of this form of plague, and a few notes of his illness are subjoined:

On January 2nd, being in his usual health, he was seized with a rigor; fever came on, with nausea, vomiting, bad headache, and a tired, aching feeling in his limbs; his temperature soon rose to $103.4^{\circ}$, but his tongue remained clean and moist and his skin was not at all dry.

On January 3 rd he had passed a bad night and felt worse, and the symptoms persisted through the day, temperature averaging $104^{\circ}$, pulse 110 , respirations 23 ; in the afternoon he felt some pain at the lower part of the left axilla, just under the anterior fold, but there was no glandular enlargement or pain in the glands anywhere.

On January 4th had slept badly and felt worse, temperature 104. $6^{\circ}$, pulse 114 , respirations 25 ; tongue still moist, with a little fur behind, but no sordes about the lips or teeth. During the night he began to cough, and brought up some watery sero-mucous fluid slightly blood-tinged; the pain in the left axilla persisted, and at this spot the fine crepitations of early pneumonia could be heard; they could also be heard just below the left clavicle, but the rest of the lungs and other organs appeared to be normal, as did the lymphatic glands. The symptoms, however, were not like ordinary pneumonia, for the onset was different, the condition of the tongue and mouth different, there was no dyspnœe or pneumonic disproportion of pulse and respiration, and the sputum was not at all like rusty sputum, for it was loose and free, coming up with the slightest cough ; it was watery, looking more like serum than mucus, and it was slightly pink, not rusty-yellow at all; also there was the striking fact that the patient's general condition was far worse than could be explained by the small amount of lung disease present so I examined the sputum under the microscope, and found it full of bacilli, looking like those of plague, and cultures were made from it from which a pure growth of the plague bacillus was obtained.

During January $4^{\text {th }}$ and $5_{\text {th }}$ the patient became worse and worse; his expectoration continued profuse; temperature about $104^{\circ}$; his respirations increased to 35 and 45 , and the pulse to 120 and 135; the tongue became rather dry and furred, and he died on January 6 th.

There is also the case of the nurse who attended on him for she, unfortunately, died of the same form of plague; in brief, she became ill on the evening of January 7 th, and showed symptoms of pneumonia on January 8th; she became rapidly worse, and died on the roth; but her sputum was not nearly so profuse as in the former case, and exhaustion came on much earlier. She also had no glandular enlargement or pain whatever, and bacteriologically her sputum was exactly as described above.

This form of plague is highly infectious, and probably takes a large share in the spread of the disease; for in these cases the patients' sputum is practically a virulent pure culture of the plague basillus, and as there is reason to believe that many of the fcases are not recognised as plague at all, pre- cautions are not taken by the patients' friends and the dangerous nature of the disease is not appreciated. I have no means of knowing how frequent this variety of plague has been in the present epidemic, but there is some evidence to show that a considerable number of cases have occurred.

Moreover, it seems likely that a ship's passenger suffering from this form of plague might escape detection by sanitary officers, and might be permitted to land at his destination as though he were the subject of simple pneumonia; and so a centre of infection for the spread of plague would be established.

With regard to the literature on this subject, I have not been able to find a published description of this variety of plague; but an allusion to it is made in the accounts of the Pali epidemic of 1836 , and it is stated that the Astrakhan outbreak of 1877 was first regarded as croupous pneumonia or as typhus complicated by pneumonia ; from the reports on the Hong Kong epidemic it appears that plague pneumonia did not occur there. There is just this to add: the usual definition of plague in works on medicine is-" $A$ specific fever, attended by bubo of the inguinal or other glands ;" but it seems that such a form of words does not include all varieties of the disease.

\section{A CASE OF DISLOCATION OF PERONEI TENDONS TREATED BY OPERATION.}

\section{By G. MUNRO SMITH, M.R.C.S.ENG.,} Assistant Surgeon, Bristol Royal Infirmary.

IT is stated that the peroneus brevis is more frequently dislocated than the peroneus longus, but in the following case both tendons were out of place. Although there was a rent

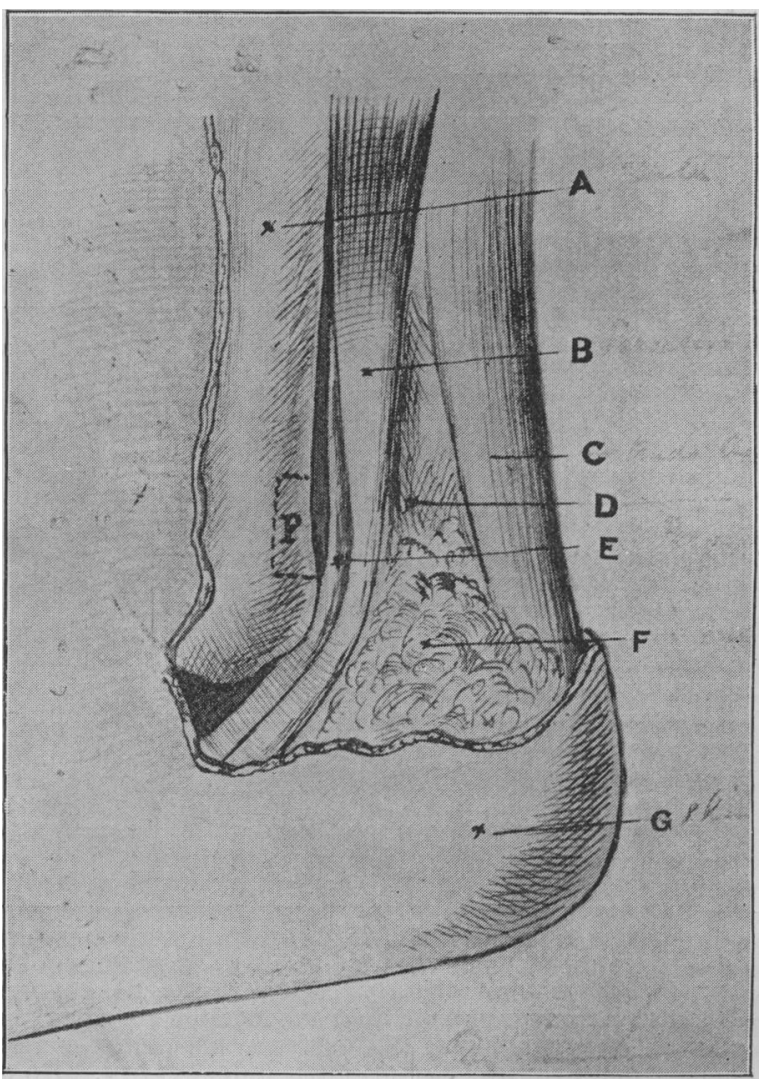

Dissection of peronei at external malleolus; at $P$ is shown the area of periosteum which was dissected back and fastened to the fascia behind the tendons, the sheath is not shown. A, fibula : B, peroneus longus; C, tendo Achillis; D, fascia ; E, peroneus brevis ; in the sheath, it was the stretching of the latter which was the chief lesion. The groove behind the tibula was very 